\title{
State-building for the market economy in Eastern Europe
}

\begin{abstract}
PAUL HARE*
Heriot-Watt University, Edinburgh Campus, Edinburgh, EH14 4AS, UK

Received: May 31, 2019 • Revised manuscript received: October 28, 2019 • Accepted: December 2, 2019

(๔ 2020 Akadémiai Kiadó, Budapest

ABSTRACT

Kornai's earlier works embodied the idea that state institutions formed a system with a strong tendency to reproduce itself, and hence to resist minor reforms. Thus, at the end of socialism, huge changes were needed in politics, economics, and the law to build a new system oriented towards the market-type economy, which would again be stable, self-reinforcing and self-sustaining. Transition promoted the development of new states in Eastern Europe that conformed to the Copenhagen criteria for the EU accession. Were we too hasty in thinking that we had succeeded? The new systems are not returning to the previous one, and only in a few areas have the basic norms of a market-type economy been set aside in Hungary or Poland. But concerns arise at the interface between politics, law and economics - to do with the rule of law, the nature and role of the state, and the interactions between parliament, the executive and the judiciary. Unavoidably, there is also an interesting international dimension here, represented by the shift from the Warsaw Pact and CMEA to NATO and the EU. This paper explores these issues in the light of some of Kornai's recent analysis of developments in Hungary, while also drawing on his very insightful earlier works.
\end{abstract}

\section{KEYWORDS}

socialism, capitalism, transition, EU accession, rule of law

\section{JEL CLASSIFICATION INDICES}

$\mathrm{N} 14, \mathrm{P} 30$

*Corresponding author. E-mail: paulhare10@gmail.com, p.g.hare@hw.ac.uk 


\section{INTRODUCTION}

Already by the 1970 s and certainly by the 1980s, it was apparent that, economically, the countries of Central and Eastern Europe (CEE) (including the then Soviet Union) were lagging further and further behind the countries of Western Europe. The economic model of central planning, with varying degrees of partial reform in different countries, was no longer delivering much growth, despite quite high rates of fixed capital investment; living standards were low and not improving much; and either shortages were endemic or external debt grew out of control. As a part of the system, most foreign trade took place within the socialist world under the auspices of the barter-like CMEA, the Council of Mutual Economic Assistance ${ }^{1}$ (also called COMECON in colloquial language). In most of the region almost all property was in state or 'collective' ownership. Underpinning the economic framework was the established system of one-party, communist rule, over which the Politburo of the Soviet Union maintained close surveillance, severely limiting the possibilities for real change, either political or economic.

But systemic change did finally come, starting in 1989 in the CEE countries, 1990 and 1991 in the Soviet Union itself. Reaching this point was not easy, and political change was widely perceived as extremely risky, given the history of the Soviet interventions in the region: Hungary in 1956; Czechoslovakia in 1968; and Poland in 1981 (martial law imposed, reportedly under pressure from Moscow which threatened military intervention to crack-down on strikes and protests). By the mid-1980s, General Secretary Gorbachev was stating repeatedly that the socialist countries should be free to choose their own paths of development, raising critical questions of trust among the partner countries. Eventually, economic crisis and political mobilisation (led by the still officially banned Solidarity Trade Union under Lech Wałesa) led Poland to make the first move. Round Table talks over two months (February-April 1989) created the office of President (separate from the ruling communist party) (Polish United Workers Party (PZPR)), a bicameral parliament (lower house, the Sejm; and a new upper house, the Senate), and agreed to hold free elections in June 1989. However, in this first free election, $65 \%$ of the seats in the Sejm were reserved for the communist party representatives, reflecting the caution and nervousness that prevailed then: the Soviet Union could still invade to block these changes, and many feared that it would do so; there was widespread relief when it opted not to intervene. Also, this initial electoral protection for the communist party was not retained for subsequent elections in Poland.

Following the Polish example, the nascent Hungarian political parties and the communists engaged in their own Round Table talks from March 1989. In October of that year the communist party (MSzMP - Hungarian Socialist Workers Party) reconstituted itself as the Hungarian Socialist Party (MSzP), establishing a new democratic Constitution and calling for completely free elections; these took place in March 1990. Other countries in the region rapidly followed the Polish and Hungarian examples, including the former East Germany (German Democratic Republic, GDR). The leadership of the GDR was already seriously divided over many important issues and realised it could not continue subsidizing the energy-intensive heavy industries by maintaining crude oil and natural gas prices significantly below the prevailing world market price. The Berlin Wall was opened in November 1989, German reunification

\footnotetext{
${ }^{1}$ The CMEA was an economic organization from 1949 to 1991, formed to coordinate the economic development of the Eastern countries.
} 
taking place in late 1990 - this required the acquiescence of Gorbachev, in exchange for some financial aid from the Federal Republic of Germany to the Soviet Union. ${ }^{2}$ In response to these momentous events across Eastern Europe, there was neither political nor military intervention from the Soviet Union, nor attempts to prop up the failing communist regimes.

By bringing their periods of communist government to an end, mostly over a very dramatic few months in 1989 and early 1990, the CEE countries were clear that this also implied an end to the Soviet-style economic management through central planning, and hence required a rapid transition to market-type economic systems. Successfully managing this transition was more easily said than done, but the main elements of what came to be regarded as the standard transition 'policy package' were quickly understood, as follows:

- Macroeconomic stabilisation;

- Price and trade liberalisation;

- Privatisation and enterprise restructuring; and

- Much institutional change.

Naturally, different countries, depending on their precise initial conditions and the quality of their initial post-communist leadership, followed quite diverse paths of reform, with varying success. There was extensive debate both about the pace of reform and about the most appropriate reform sequencing (Portes 1991; Hare - Révész 1992; Dewatripont - Roland 1995; Gros Steinherr 2004; Turley - Luke 2011). These papers argued for gradual reforms and against a 'Big Bang' approach. In any case, several of the newly independent countries, notably among the countries that emerged from the USSR (from which there were 15 successor states) were very slow to acknowledge the need for major and wide-ranging political and economic reforms to support a shift to building market-type economies.

An important aspect of these transition processes, everywhere where the goal of transition to a market-type economy was quickly accepted, was the enormous emphasis given to institutional reforms across all areas of economic and social life.

Quite soon it became clear that some of these former communist countries, notably the Baltic States, and those in Central Europe, not only wanted to shift quickly to the market-type economic system, but also sought to move over from the Eastern system of alliances (COMECON and the Warsaw Pact) to the Western system (the EU and NATO). This simplistic picture was greatly complicated in the early 1990s by the disintegration of the former Yugoslavia and the ensuing civil wars that soon erupted in the Balkans, the fighting only ended by the Dayton Peace Accords of 1995. Even today, though the Balkans are calm and peaceful, it would be premature to claim that the countries in this corner of Europe were living together in peace and harmony. The politics of the region are still difficult, and sensitive, to put it mildly.

The EU was quick to offer aid to assist with transition, and quick to support some of these aspirations to move to the Western system of economic and military alliances, but it did so quite selectively, initially by means of Association Agreements and then by allowing - for some countries, the opening of the EU Accession negotiations. Countries in the queue for accession not only had to

\footnotetext{
${ }^{2}$ The agreement on aid was based on a three-day meeting between Chancellor Kohl and President Gorbachev in mid-July 1990, held in Moscow and Stavropol. Sums estimated to lie in the range of $€ 25-40$ billion were to cover costs of relocating Soviet troops back to the (then) USSR, and to help stabilise Soviet finances. Given the demise of the USSR just over a year later, it is not clear how much of these agreed sums were ever actually paid out.
} 
accept the basic Copenhagen criteria, ${ }^{3}$ but also had to adopt, and incorporate into their domestic legislation, all chapters of the EU's acquis communautaire, a formidable undertaking. (For a thorough review of the EU's architecture see Hare and Stoneman (2017)). Not surprisingly, the ensuing accession processes proved to be slow and complex. In 2004, 8 CEE countries joined the EU (Estonia, Latvia, Lithuania, Poland, Czech Republic, Slovakia, Hungary and Slovenia). In 2007, two more joined, Bulgaria, Romania, and finally in 2013, Croatia joined the EU. Other transition countries have been accepted as candidates for accession, though the associated negotiations are currently proceeding at a glacial pace, ${ }^{4}$ the whole process having lost much of its momentum, for a mix of political and economic reasons. For other countries in the region not considered as the candidates for accession (for many different reasons), the EU has developed a Neighbourhood Policy that has resulted in various forms of Association and Free Trade Agreement, for instance with Ukraine and Georgia, to mention just two. It is interesting to consider whether Ukraine's transition - (both economic and political) might have proceeded more smoothly, perhaps even with smaller economic losses, had the EU been more welcoming right from the start (Hartwell 2016a).

The problem is, for those countries that have now joined the EU, signing up to the EU entailed much more than making the core reforms needed to establish a tolerably well-functioning markettype economy. For it meant adopting far more wide-ranging and intrusive economic measures (to do with regulation and the like) than one might have advised these countries to implement had they not been seeking the EU membership. Further, it also involved adopting the EU's political model as set out in the Copenhagen criteria and the more political chapters of the acquis communautaire. Essentially, therefore, by the time they became the EU member states, the selected CEE countries had adopted the entire EU model, both its economic arrangements and its political practices (see Lisbon Treaty (2007). Even though one can well understand the political imperatives that brought us to this point, the important question that now arises is whether this model is actually viable and sustainable for the countries concerned. Logically, the question breaks down into two parts:

(i) Is the complete EU model needed to underpin a well-functioning market-type economy?

(ii) How far does the EU model conflict with the cultural and historical realities of some of the New Member States, and how important are such conflicts for their economic models? ${ }^{5}$

In what follows I explore some aspects of these questions, especially part (i). To do so, I start by reviewing some of Kornai's work and drawing out some relevant lessons since this provides the underlying conceptual framework for the paper (Section 2). Next, I sketch some of the recent political developments in Hungary and Poland (Section 3). This leads into an analysis of the rule

\footnotetext{
${ }^{3}$ The accession criteria or the Copenhagen criteria (after the European Council in Copenhagen in 1993 which defined them) are the essential conditions that all candidate countries must satisfy to become a member state. These are:

(1) political criteria: stability of institutions guaranteeing democracy, the rule of law, human rights and respect for and protection of minorities;

(2) economic criteria: a functioning market economy and the capacity to cope with competition and market forces; and

(3) the administrative and institutional capacity to effectively implement the acquis and the ability to take on the obligations of membership (EU Neighbourhood policy website).

${ }^{4}$ Indeed, the October 2019 European Council meeting decided to put on hold accession negotiations for both Albania and North Macedonia.
}

${ }^{5}$ For a wide-ranging review of economic growth and the factors that support it, see World Bank (2008). 
of law, the nature of the state, and Parliament and the Executive (Sections 4 and 5). Section 6 pulls the main findings together and concludes.

Kornai's work is extremely relevant and helpful in exploring the issues to be reviewed in this paper. First, his earlier work in particular provides some of the best available analysis of the old system of central planning and comprehensive economic management by the state. Second, much of his later work seeks to characterise how a market-type economy should function, and at times this analysis includes a model for a fully developed capitalist economy. Third, in this sort of analysis there is a tension between the economics of the capitalist model and the politics of the model, and thinking about this tension helps to clarify some aspects of questions (i) and (ii) above, as I illustrate later on.

\section{KORNAI'S WORK AND LESSONS TO BE DRAWN}

For space reasons, it is clearly impossible to refer to all of the works of Kornai that would be relevant for this paper, and I shall therefore be extremely selective. On the workings and failings of central planning, I refer very briefly to Kornai (1959, 1972, 1980); on the functioning of capitalism, Kornai (2013); and on the recent developments in Hungary in particular, Kornai $(2015,2019)$. Many other significant works by Kornai could just as well have been cited.

\subsection{Central planning}

The really essential point here, brought out remarkably early by Kornai (notably in Kornai (1959)); but elaborated in much greater depth conceptually in Kornai (1980), is that central planning was not a bad system due to avoidable administrative deficiencies or poor economic leadership. Quite simply, it was inherently a bad system for running an economy. ${ }^{6}$ Informational and incentive issues identified by Hayek among others partly explained this, as did Kornai's understanding of the feedback mechanisms that operated within a centrally planned economy to ensure its inefficient functioning. Thus, partial reforms (such as reducing the number of compulsory plan indicators) always failed, as the internal workings of the system generated pressures to restore something like the status quo ante. Planned economies tended to generate shortage conditions (often associated with queues and rationing), were inimical to innovation, and state-owned enterprises enjoyed 'soft budget constraints' (SBCs). In the early post-war decades, the centrally planned economies did manage to generate quite respectable growth rates of GDP, though slower growth rates of consumption/living standards due to the over-emphasis on heavy industry. But the centrally planned model for the economy ran out of steam (and in many countries, of foreign credit possibilities), and the political leadership in various countries was too rigid to allow any significant experimentation with alternative models. ${ }^{7}$

Piroska - Rosta (2020) also highlighted another very important point by referring to the works of Jánossy (1966) and Kornai (1972). In the 1950s and 1960s, it was arguable that

\footnotetext{
${ }^{6}$ See Hayek (1944, 1945), also Hare (1991); and specifically, on the soft budget constraint, Robinson - Torvik (2006); Maskin (1996) and Maskin et al. (2003).

${ }^{7}$ Perhaps China, and more recently Vietnam, have learned from this bad experience in Eastern Europe, since they have allowed a great deal of market-oriented reform, even moves towards (quasi-) private ownership, while retaining Communist Party's overall political control, along with still substantial state ownership.
} 
Hungary's economic growth was too fast to be sustainable - and so it turned out - while also being extremely erratic and irregular. Jánossy saw Hungary's early post-war rapid economic growth not as a triumph of sound economic planning but simply as a normal period of recovery following the wartime devastation of the country. Kornai also saw the growth over this period as unlikely to be sustained, and he pointed to the associated shortages, poor quality and variety of products, and other shortcomings. These were not 'problems' that would gradually disappear, they were - according to his analysis - inherent to the functioning of the socialist system. Arguably, Hungary's growth over the last decade can also be viewed in part as a process of gradual recovery from the world financial crisis of 2007-2009, illustrating, too, the inherent inefficiency of Hungary's present nationalist-populist system.

\subsection{Functioning of capitalism}

In sharp contrast to the poor functioning of socialist economic systems, Kornai (2013), building on much of his earlier work, highlights some of the key institutional features that have enabled capitalism at its best to be economically successful, and to generate high and growing incomes. By using here, the phrase, 'capitalism at its best', I am interpreting Kornai to mean an idealised form of capitalism, largely free from corruption and rent-seeking, supported by a strong institutional framework to protect private property as well as the processes of private capital accumulation. As Xu (2017) explains in his very interesting review of Kornai's book, Kornai normally sees capitalism as being underpinned by private-property rights, market coordination and entrepreneurship. Taken together, these tend to generate conditions of surplus (in contrast to socialism's shortage), support hard budget constraints (HBCs) (in contrast to socialism's SBCs), and foster innovation and the constant renewal of production. Departing from the equilibrium theories of mainstream neoclassical economics, Kornai sees capitalism as fundamentally dynamic, undergoing processes of creative destruction as was first discussed by Schumpeter (1942). In this model, innovation not only brings down production costs for existing and well-established products and services, but far more importantly, it results in new products that can rapidly displace the old ones. This is the creative destruction. Generally, private businesses are not protected by SBCs (e.g. subsidies, directed credits and other forms of state intervention) that might allow failing firms to survive, hence their survival depends on maintaining their competitiveness in an ever-changing market.

In practice, neither socialist nor capitalist systems exist in completely pure forms. Thus, even the most centralised socialist economies, as in the former Soviet Union, allowed limited operation of private production and markets, as in the widespread private-plot production and sale of foodstuffs, for instance. However, the scope of such private endeavours was always heavily circumscribed, subject to periodic crackdowns, and with no one enjoying private property rights that were assured, well defined and protected. Consequently, such activity was never permitted to develop sufficiently to threaten the basic internal logic and dynamics of the socialist system.

In the capitalist economies, too, there are often some state-owned firms, commonly in key infrastructure sectors; public bodies delivering essential services (such as the UK's National Health Service, or NHS), along with diverse public services delivered by private firms. The latter firms are often selected by competitive tender, usually operate with fixed -term contracts, and are expected to achieve a range of performance indicators. Despite the best efforts of the public authorities responsible for overseeing these diverse activities, however, the reality is that it 
proves to be politically and economically difficult to enforce HBCs on these activities and firms. Knowing this provides opportunities for gaming the authorities in ways that limit competition, raise costs, and probably also constrain innovation. This gives rise to a common dilemma in the capitalist economies, namely how to ensure that public services are delivered to a good standard without interruption, while also keeping costs down, as well as fostering innovation and competition among service providers. Different countries find different, and quite diverse solutions to such dilemmas, none absolutely perfect. On property rights and their vital role in development (e.g. by ensuring that people have secure title to their property, which enables them to take out loans and offer suitable collateral), the Peruvian economist, Hernando de Soto, has had important things to say, much of which echoes and reinforces Kornai's own thinking (e.g. de Soto 2000; Williamson 2010). Woodruff (2001) provides an interesting review article on de Soto's work, suggesting that successful implementation of de Soto's ideas about property rights will often require extensive institutional, and perhaps even political reforms, going beyond the formal, legal provisions regarding property rights.

That said, it remains the case that the core institutional features of a capitalist economy concern the protection of private property rights (often discussed under the heading, rule of law), market coordination (implying the absence of coordination by command or through an administrative hierarchy), and entrepreneurship (with no one needing official permission to set up a new business, or to pursue a new idea or business model). These are powerful conditions, and for all their undoubted and sometimes huge shortcomings, they have mostly served us well. However, Hartwell (2016b) reviews the evolution of property rights in both Poland and Ukraine, examining the interplay between these rights and political power. He shows that the periods of political centralisation have proved inimical to efforts to secure property rights; and conversely, even supposedly established property rights can be undermined by the exercise of political power.

\section{RECENT DEVELOPMENTS IN EASTERN EUROPE}

In the past few years, both Hungary and Poland have elected nationalist/populist governments which have chosen to implement measures that strengthen the power of the Executive over courts, the public media and the judiciary, and which have enhanced government powers in other areas, too. Both countries, along with some other CEE countries, have resisted attempts by the European Commission (EC) to persuade them to accept a designated share of recently arrived immigrants to Italy and Greece and efforts by the Commission and the European Court to persuade them to comply. In Hungary's case, so strong has been the opposition to these new arrivals that new border fences and controls have been erected along the country's Serbian border. The Hungarian government used this one-time tide of migration as a pretext to declare a 'terror threat' (without any evidence of terrorist actions before that) and introduced martial-law like provisions in the Constitution. In managing the recent migration crisis, collective action by an EU working together in broad harmony has clearly failed. Indeed, the December 2017 meeting of the European Council came close to acknowledging this failure, when it proposed that some alternative to the present mandatory quotas was needed, though not yet specifying the likely shape of such an alternative. The most recent attempt to manage the migration issue - at the June 2018 European Council meetings - still lacks credibility. 


\subsection{Hungary}

Kornai (2015), with an accompanying commentary, Hare (2015), documents Hungary's U-Turn, and also draws on detailed research by Scheppele (2012) showing both a weakening of democratic norms and safeguards as well as significant re-centralisation of much economic management. Opinion (2012) also provides some useful insights.

Even before the 'official' start of the transition in late 1989, Hungary was quite well placed, as the country had already dismantled the more centralised aspects of planning, allowing enterprises substantial freedom to operate independently, and permitting various forms of smaller business to be established. Hence it was not really surprising that during the 1990s, Hungary showed rapid progress in transition as measured by the EBRD transition indicators published each year (see EBRD Transition Report, various years). This evolution was undoubtedly aided by the large inflows of FDI attracted into Hungary. Similarly, the country was quick to implement most of the EU's acquis in preparation for accession. Thus, by the time of its entry to the EU in 2004, Hungary had a well-functioning market-type economy based on private markets and the protection of property rights, and it fully complied with all the EU membership conditions. This included compliance with those political provisions concerning democracy, protection of minority rights, and the like. Hungary has not yet chosen to adopt the euro and join the Eurozone, though 'eventually' (at some unspecified date) it is treaty-bound to do so. Indeed, up to 2010 the Hungarian government did publish a target year for adopting the euro, but has since abandoned any such explicit commitment, the National Bank claiming that joining the eurozone could be harmful for the economy.

Despite starting transition with high international indebtedness and a determination not to default (for which several observers at that time criticised Hungary quite sharply), Hungary managed its macroeconomic policy in the early transition years remarkably well. The country experienced a longer and deeper post-socialist recession than Poland did, but modest economic growth had resumed by the mid-1990s. Moreover, after 2004, the EU membership still left significant degrees of freedom for domestic policy-making, and many people in Hungary were disappointed at the country's slow catch up to the living standards of more developed member states. There was nevertheless some significant catching up. However, it was not until 2010, with the election of a new Fidesz government led by Viktor Orbán, and enjoying a two-thirds majority in the Parliament, that Hungarian politics started to change rapidly. Moreover, Orbán won the next two elections in 2014 and 2018, still with a two-thirds majority. In neither case, however, did Fidesz achieve a majority of the popular vote, and there were widespread allegations of ballot rigging.

Since 1989, it had been understood that proposals for constitutional change should involve wide consultation, including with the main political parties, but the Fidesz government was able to devise and pass a new Constitution for Hungary (termed the Fundamental Law) that came into force at the start of 2012, buttressed by an array of the so called Cardinal Laws which themselves require a two-thirds majority in the parliament before they can be changed see Scheppele (2012). These important changes in Hungary's constitutional order came about with virtually no consultation across the political spectrum.

Moreover, the new constitutional order greatly narrows the normal 'gap' between the executive power and the legislature, weakening or removing many democratic safeguards. The judiciary, too, can no longer be considered fully independent of the executive, one of the major 
concerns of Halmai - Scheppele (2012). Separate administrative courts were established, some newspapers and magazines had to close, much research funding was removed from the Academy of Sciences and the universities, and the National Bank lost much of its independence. Thus, both the separation of powers and the rule of law (on which see Council (2018)) have been undermined, as I discuss further in Sections 4 and 5. Further, important parts of the state apparatus have undergone significant centralisation, with local governments losing their former powers over schools and parts of the health service, for instance. At the same time, a degree of creeping privatisation, with some recent deals lacking transparency and openness, can be seen as weakening private property rights in Hungary. Sometimes the government has arbitrarily withdrawn business licences from entities such as banks, utilities, savings cooperatives, tobacco shops and gambling businesses, among others; and has transferred ownership to close associates of the ruling party.

The EU, of course, has followed these developments in Hungary with interest and concern. The Commission did challenge the new Hungarian constitution in 2012 and 2013, requesting 'clarifications' from the Hungarian authorities. Although both the Commission and the European Parliament have favoured adopting active measures to bring Hungary back into line with basic democratic principles, the EU member states have been reluctant to act (Grabbe - Lehne 2017). Hence little has been done and Orbán has not found it too difficult to resist EU entreaties. More recently, the Commission has referred Hungary to the European Court of Justice over two matters: (1) Hungary's failure to cooperate with Brussels in regard to implementing immigration quotas; and (2) New laws about higher education and NGOs receiving foreign funding. The latter are seen as indirectly undermining the legal standing of the Central European University in Hungary (which eventually was forced to be relocated to Vienna), and have provoked widespread international, and less widespread but significant, domestic protests. In addition, in June 2018 the European Parliament also called for Article 7 action against Hungary to be considered, based on the findings of a report from the Committee on Civil Liberties, Justice and Home Affairs (Sargentini 2018).

In short, the substantial recent changes in Hungary's constitutional order and related legislation serve to undermine the 'rule of law' as well as the 'separation of powers'. This gives rise to three inter-related questions important for the present paper:

Q1. Are the political and economic changes recently experienced in Hungary sufficient to undermine the functioning of the market-type economy in the country?

Q2. Additionally, do these changes, and other recent policy developments in Hungary, significantly conflict with Hungary's compliance with the EU's acquis communautaire, notably its political chapters?

Q3. Last, can we point to any internal dynamics within the Hungarian economy and political system that might lead to a reversal of recent changes?

Briefly, the answers to Q1 and Q2 appear to be 'yes', though it is too early and, in any case, unclear whether these answers yet imply notable economic harm to Hungary. Such harm could take the form of reduced inflows of foreign investment, lower GDP growth rates, and perhaps more emigration of highly skilled people. Apart from the recent low FDI inflows and worsening competitiveness indicators, to date there is a little firm evidence for these kinds of impact. The underlying point here, is surely that full compliance with the acquis, notably the numerous chapters that have evolved over time as the EU has expanded its remit to cover many regulatory 
aspects of economic management, are not really crucial for the sound functioning of a markettype economy, so that doing things differently from what the acquis would strictly prescribe cannot be said to be necessarily and economically harmful.

In thinking about a still evolving political and economic system such as that of Hungary, it is important to have in mind its internal dynamics, which was Q3 above. Thus, to draw on ideas of Kornai, does the system possess an internal logic that inherently steers it in certain directions rather than others? And just as important, it is often important to distinguish between the official 'rules of the game' as they are formalised in legislation, regulations and guidelines, and how they function in practice through informal understandings and working conventions. This depends as much on the people holding certain key positions, as on the formal laws.

Regarding Q3, therefore, I am a little less pessimistic than Kornai. Kornai sees many of the recent changes in Hungary as entrenched by the ruling party's use of its two-thirds majority in the Parliament to make future constitutional changes, changes to Cardinal Laws and other new regulations and practices exceptionally difficult. This is an important point, and while the Fidesz Party remains strong, and while former governing parties still suffer from a serious lack of trust and credibility, nothing is likely to change very soon. But this situation can change, with Fidesz by no means guaranteed to remain in power more or less indefinitely. True, it would be surprising if another party secured a two-thirds majority, but constitutional amendments and other changes can still come about by consensus across party lines, and nothing that has so far occurred in Hungary prevents this - eventually. This doesn't quite amount to a dynamic that guarantees to restore the status quo ante, but it does show that the possibility is not (yet) ruled out. Clearly the Fidesz government led by Orbán has undermined democratic values (Lendvai 2017), and this is already a great concern to the EU as I examine more carefully below. But the changes already made could still be rolled back, albeit not easily.

Against this perhaps naïve notion of mine is the observation that not only in Hungary, but elsewhere in Eastern Europe (e.g. Poland, as I discuss next), there is a limited historical experience of democratic government, and a good deal of popular sympathy for relatively autocratic and nationalistic rule. Thus, those parts of the acquis that concerned democracy, the judiciary, protection of minorities, protection of the media etc., all had to be adopted and taken on board along with everything else, in the course of the EU accession negotiations. However, it is worthwhile to question how firmly 'embedded' the provisions in these areas became in the region's nascent democracies. This is not clear yet.

\subsection{Poland}

In the early transition years, Poland was lucky in its political leadership and economic management, with the result that its post-communist recession was the shortest and shallowest in the region, and by 1992 the economy was already growing quite rapidly. The economy modernised quickly, and incomes rose both absolutely and relative to the EU average. In other words, there was significant catching up, albeit from a lower base than Hungary. The growth was accompanied by a good deal of restructuring, while unemployment rates remained stubbornly high. Nevertheless, some of the pressure in the job market was undoubtedly eased by the free movement of labour within the EU, in effect from 2004 with the UK, only later with other member states, which opted to maintain some labour market mobility restrictions for some years after Poland's accession. Although receiving almost no foreign direct investment until the 
mid-1990s, once Poland finally reached a settlement (and significant debt relief) with its external creditors, FDI grew rapidly as the country was able to offer a well-educated workforce, and access to the EU markets well ahead of the 2004 EU accession.

Poland has continued to perform economically well and easily managed the 2007-2009 world financial crisis impressively, experiencing at most a minor and short-lived slow-down in growth (Gradzewicz et al. 2014). This might have been helped by the fact that Poland had not joined the Eurozone (and still has not, even though its sound economic management would enable it to meet the Maastricht conditions), and was thus largely unaffected by the difficulties facing the zone. But the effective supply-side policies undoubtedly also had a positive impact. According to OECD (2018), the Polish economy continued to grow at respectable rates, normally over $4 \%$ p.a., and unemployment fell, leaving a tight labour market. There is a need to strengthen the country's capacity to innovate, by investing more in higher education and R\&D. The OECD sees enhancing skills as critical for future growth.

In Autumn 2015, Poland's Law and Justice Party won a majority of seats in the Sejm (lower house of parliament), and formed a new government, led by Beata Szydło until late 2017 (she was replaced by Mateusz Morawiecki, the former Finance Minister, in early December). She is a deputy leader of the Law and Justice Party, whose head is Jaroslaw Kaczynski. Thus, he effectively determines the policy orientation of the party and government, and both leaders (as well as the new Prime Minister) share the party's pro-welfare and anti-migrant stance that secured their election success. Their goal is both to appeal to traditional Polish values regarding the family and the church, while helping those perceived to have benefited little from Poland's rapid development. Since the election, the government has delivered on its promises to improve social benefits. It has also taken several steps to enhance executive control over the judiciary leading outside observers like the Venice Commission to raise concerns over the rule of law, and more recently (like Hungary) Poland has not cooperated with the EC in accepting its allocated share of recent migrants from the Middle East and Africa.

Just as for Hungary, this has led to the EU starting an enforcement process against Poland. In fact, in December 2017, the European Council invoked Article 7 of the Treaty on Economic Union for the very first time, an action that some have described as the 'nuclear option'. The first 'stage' of an Article 7 intervention involves the Commission submitting to the 'offending' member state's government a 'reasoned proposal' explaining how the principles of the rule of law are being violated, and specifying what actions are needed for the government concerned to comply once more with the EU treaties. The Commission (2017) did this for Poland, giving the government three months (i.e. until late March 2018) to respond. Poland did finally propose some compromises with the EC over its legal reforms and requested that the Article 7 action to be withdrawn. The Commission declined, and an agreed settlement has not yet been reached. Failing a satisfactory outcome, Article 7 provides for further measures, including the possible suspension of Poland's voting rights in the Council. However, this step requires a unanimous vote by all member states other than Poland, but Hungary has already stated that it would not permit such a vote to go through.

Interestingly, the Commission (2018, p. 4), in its draft proposals for the EU budget for 20212027, introduces a new mechanism that could financially penalise the member states judged to depart from compliance with the 'rule of law' in ways that 'impair sound financial management'. How this could work is not yet very clear, but it would be implemented by qualified majority voting. Indeed, the incoming Commission President, Ursula Von der Leyen, has already 
proposed (Commission 2019) that there should be annual monitoring of the member states' compliance with the Treaties' provisions regarding the rule of law. These proposals have already attracted strong criticism for their weak enforcement arrangements. Policy in this area is still evolving.

\subsection{Indicators of freedom and democracy}

Poland and Hungary still think of themselves as democratic states, essentially operating in accordance with the loosely defined western model of parliamentary democracy, accompanied by the rule of law and a proper separation of powers. However, the way they each operate this 'model' is conditioned by their respective histories and cultures. Seeking to be objective and fair, it is useful here to refer to some external assessments of these countries to see how they have been judged both in terms of indicators of their levels of freedom and democracy, and in terms of recent changes in such indicators. After briefly reviewing these political indicators, I then look at the World Bank's Doing Business indicators to see whether they might have responded to recent political developments, and last the World Economic Forum's Competitiveness indicators.

According to Freedom House reports, there is a significant contrast between political developments in Hungary and Poland. Hegedüs (2017) reports that over the past decade, Hungary's scores on a whole range of democracy indicators have steadily worsened, the aggregate democracy score changing from 2.14 in 2008 to 3.54 in 2017. Correspondingly, Hungary's overall freedom rating fell by over 20 points in the last decade, falling to 72 , leaving it with the lowest score among the EU member states (FH, 2018). For Poland, Arak - Bobiński (2017) show a more mixed picture, with some democracy indicators improving, some mildly worsening over the decade. From 2008 to 2012, the aggregate democracy score was on a slightly improving trend, but since then it has slowly deteriorated, with a notable worsening from 2.32 in 2016 to 2.57 in 2017. The country's overall freedom rating in 2017 was still good, at 85 . This apparent contrast between Hungary and Poland is confirmed by the most recent reports of the Bertelsmann Stiftung (see BTI, 2016a, 2016b).

World Bank (2017) shows that Hungary's business environment is rated rather worse than that of Poland, though on some measures, such as ease of doing foreign trade, Hungary performs better. Recent Doing Business reports do not (yet) suggest any noticeable impact of the latest political changes on the ease of doing business. Indeed since 2010, Poland had come up in the overall rankings from 72nd to 27th in 2017, a very marked improvement. Over the same period Hungary's ranking has been static, coming in at 47th in 2010 and 48th in 2017. In terms of competitiveness, Hungary was ranked as 60th out of 137 countries in World Economic Forum ranking (WEF 2017), a marked improvement over the previous year, though similar to early years of the decade; the latest change was mostly due to improvements in 'technological readiness'. Poland was ranked higher, at 39th, a position not much changed during this decade.

\section{THE 'RULE OF LAW'}

The rule of law is a complex and quite subtle idea, commonly misunderstood (Bingham 2010). With regard to the economy, it requires that private property rights (ownership, business 
contracts, etc.) are legally protected against infringement either by other private agents or by agents of the state itself. Such protection is not merely desirable per se, but is important for its role in creating the conditions to stimulate investment and innovation. For a predominantly private-sector economy to function well, it is also important for the state itself to enjoy similar protection against malfeasance by private agents (which includes both corruption in its diverse forms, as well as rent seeking), or indeed by other parts of the state. This last point implies that public ownership includes not just a state-owned firm at the national level but also ownership by, say, a local authority or regional government. These different levels of ownership also need due protection under the law. ${ }^{8}$

As regards the civil society, the rule of law requires a similar duality: legal protection for citizens to ensure that both civil wrongs and criminal offences are treated with due process, in an open and transparent manner; and that citizens may also seek legal remedies against improper (and possibly illegal) actions by the state and its agents. Citizens also need mechanisms to challenge actions and decisions undertaken by the state (e.g. in the UK we have a process called judicial review, as well as provision for occasional public enquiries, often judge-led). Moreover, citizens, firms and other organisations undertaking such legal action should not themselves face threats, obstruction or other abuses of sound judicial practice.

Taken together, all these quite correctly convey the impression that a democratic state operating in accordance with the 'rule of law' is likely to seem quite messy, with lots of procedures and arrangements to block or delay significant change at the higher levels, along with much protection for individual citizens and private firms. Democratically elected political leaders might well find this frustrating, and seek remedies that enable them to speed up change and act more decisively; this is precisely why the constitutions of democratic states tend to embody numerous 'checks and balances', deliberately making change more difficult, and providing alternative 'channels' to protect private agents, both individuals and firms. Usually this includes an active and free media, which politicians commonly dislike. In a democracy, they have to learn to live with it. This is why restrictions on and political interference with the media in Hungary and Poland are such concerns. Most importantly, the available checks and balances must be widely respected, and should not casually be set aside or ignored at the whim of politicians or their associates seeking to gain improper advantage.

Can much be said about the institutional framework' required to support the 'rule of law' in the sense outlined here? To keep the argument focussed and brief, I limit myself to a short list that could readily be elaborated in great detail:

- Sound laws guaranteeing private property, protecting business transactions and contracts.

- Laws to protect private individuals and private organisations in their dealings with the police, the courts, etc.

\footnotetext{
${ }^{8}$ At the start of the transition from socialism to the market-type economy, when privatisation was everywhere under active consideration, the nature and 'location' of state ownership suddenly came to matter. In several countries, consequently, the first stage of privatisation was a scramble by different parts/levels of the state to establish who owned what. Previously, this had not mattered at the least. For under central planning, who cared whether a particular enterprise 'belonged' to Moscow City, the surrounding oblast, or an all-Union ministry?

${ }^{9}$ In a development context, this is discussed very nicely in Dam (2006).
} 
- Laws to guarantee such fundamental rights as freedom of assembly, freedom of speech, etc. But also, laws to protect minorities whether defined in terms of ethnicity, religion, sexual preferences, etc.

- Independence of the police service, the legal profession and the courts from the legislature (Parliament), with very limited and carefully constrained oversight from the executive.

- Independent media, not under the control of the executive, and with extensive freedoms to report. Laws on media ownership and regulation (e.g. to prevent monopoly, and abuses associated with heavily concentrated ownership).

- Requirements for government to operate openly and transparently, with significant reports normally published promptly; ministries and government agencies accountable to parliamentary committees which not only conduct enquiries, but also publish their evidence and findings openly and promptly.

- All public bodies in receipt of public funding to be subject to audit or other appropriate form of review by agencies set up for the purpose, free to produce and publish reports on topics of their choosing (though within the broad remit defined in law), substantially independent, though possibly accountable to the Parliament. The point of such an audit requirement and framework is to provide some assurance that public resources will be properly used, both to fulfil the agreed goals of any given organisation being audited; and that public funds will be used cost effectively.

- Published codes of conduct in place for ministers, members of parliament, civil servants and the like, with significant penalties for breaches, and

- A legal framework to deter corruption by politicians and state officials at all levels, preferably overseen by an independent body vested with strong powers, and with substantial penalties for those found guilty of corrupt actions and behaviour in a court of law. Moreover, an important principle in such cases is that those suspected of or accused of abusing their positions and powers should not themselves investigate or adjudicate their own cases.

As soon as a list like the above is written down it is apparent that in many countries, several of the proposed provisions would prove to be seriously problematic. Most evident in this connection is the last provision on my list, concerning corruption, which several countries in Eastern Europe reportedly experience on a large scale. Not only does corruption distort competition, and serve to enrich an undeserving few, more importantly it can deter investment, slow down economic growth, and hence damage everyone's living standards (except those most engaged in corrupt activities and deals). But politically, corruption can be an extremely challenging issue to tackle effectively, because of the powerful interest groups likely to be benefiting from it (Rothstein - Varraich 2017). The EU's Anti-Fraud Office, OLAF monitors and fights various aspects of corruption in the member states, and both Poland and Hungary have significant numbers of on-going investigations, and in relation to the spending of the EU funds, Hungary appears to be the most problematic country (OLAF 2018).

The second most problematic issue is the third in my list, to do with the fundamental rights and minorities. Provisions on these matters were essential for the EU accession, and good practice is clearly regarded as a core element of the EU's notion of a 'democratic Europe'. But to some degree the area cuts across the historical and cultural traditions in the new member states, such as support for the Catholic Church in Poland. Hence in some countries, enforcing these rights as understood by Brussels is not seen as a great priority, nor it is considered to have much impact on economic functioning.

None of the other issues on my list is straightforward in the sense of being easy to legislate for and implement, not least because effective implementation requires firm political 
commitment. This is far from always assured, partly because much of the above institutional framework was put in place very quickly, and countries are still learning what works (for them), what doesn't, and how to make changes that fit local conditions - based both on cultural norms and traditions and on the relevant local history, all without losing sight of the core principles.

Nevertheless, a properly implemented set of provisions to assure the rule of law is very likely to be significantly self-reinforcing in Kornai's sense, at least as regards its impact on the functioning of the economy. This is because contract violations and other economically harmful behaviour can be challenged in the courts, and successful judgements against either harmful private behaviour or against unlawful actions by the state should be enforced. If all these work properly, it serves to create expectations and a climate of opinion in which legally correct behaviour increasingly becomes the norm. That said, for such a mechanism to work credibly and effectively, what matters is not merely the formal rules of the game, but the incumbents occupying various key positions. What happens, for instance, if a state agent simply ignores an unfavourable judgement, or even worse, arranges for new legislation to cover the case, perhaps even taking effect retrospectively (well understood to be a very bad legal principle)? Likewise, what happens if a wealthy and politically well-connected private agent ignores an adverse legal judgement? If such things can happen with impunity, then the rule of law is already a lost cause.

\section{THE NATURE AND ROLE OF THE STATE: PARLIAMENT, THE EXECUTIVE, LAW AND ORDER}

A state is well functioning if it serves its citizens properly. This can be expected only if the citizens are the master of the state and the state is their servant. However, the citizens are not strong enough to control their servant. Their only hope is to split the state into various branches which check each other's ambitions to evade controls and accumulate extreme power. To achieve this, there must ideally be a clear separation between the legislature, the executive and the judiciary. So important is this notion that it is often simply referred to as the 'Separation of Powers'. The idea was touched on in the previous section, now I elaborate it a little more. The US Constitution was explicitly and deliberately written to embody a clear separation of powers between the legislature (i.e. Congress, comprising a lower house, the House of Representatives; and an upper house, the Senate), the executive (led by the elected President, with senior Cabinet appointees being appointed by the President, subject to confirmation by the Senate) and the judiciary (system of Federal courts led by the Supreme Court, whose judges are appointed on the recommendation of the President, subject to confirmation by the Senate, but otherwise wholly independent of both the legislature and the executive branch).

In many other democratic countries, the executive (often simply termed, the government) is drawn from the legislature, though the government's activities and decisions have to conform to the laws currently in effect. Moreover, it is common practice that a government cannot legally or constitutionally function without a budget in place that has been presented to and approved by the legislature. The legislature is generally independent of government and the judiciary, including the highest court, a supreme court or in some countries a constitutional court; at most there will be limited opportunities for the government and/or the legislature (e.g. through some form of judicial appointments committee) to have a say over the most senior judicial appointments. But such an influence is normally very constrained, and properly so. 
The UK stands out here as departing from this 'standard' model. First of all, we have never had a written constitution, ${ }^{10}$ despite a long history of writing constitutions for the countries of our former Empire, as part of their progress towards independence from Britain. Second, for centuries the top level of our court system was, essentially, a committee of the House of Lords (the upper chamber of our Parliament), comprising the Law Lords. It was therefore formally part of the legislature, rather than being properly separate as the 'separation of powers' doctrine would entail. Since 2009, we have had a Supreme Court, created as part of the Constitutional Reform Act, 2005, and the 12 Justices who sit on the court are now barred from sitting in the House of Lords. Belatedly, therefore, we have taken some steps towards achieving a clearer separation of powers (Benwell - Gay 2006).

What the UK's recent experience illustrates, though, is surely the importance of distinguishing between form and substance in constitutional matters. On the surface the UK looked like a country with very limited separation of powers, but there are various checks and balances in place, such as the powers of the Upper House to delay or amend legislation; the many independent ombudsmen; the Queen herself (and occasionally, her Privy Council); the strong local governments (including the City of London); some regions with significantly different legal systems (notably Scotland); and at present the special position of Northern Ireland, whose Democratic Unionist Party ${ }^{11}$ could still bring down the British government.

Related to these institutions and independently of them, there are conventions and practices in place that enabled what looked like a poorly designed system to function rather well. This is often the case. But it can cause problems for the EU institutions seeking to verify whether one or other constitutional norms are fulfilled in a given country being examined. For it is all too tempting to make a judgement based on the formal arrangements (i.e., very much a box-ticking approach), without digging down more deeply to learn how a system really functions. This depends on a whole range of informal understandings and practices, in addition to the formal arrangements themselves. As noted above, how a system actually operates also depends a great deal on widely held expectations and understandings about 'how things work'. Confidence about these understandings is far harder to achieve in countries with a shorter experience of democracy, and where democratic practices might not yet be deeply embedded in the working assumptions of their political and economic models.

For Hungary and Poland, recent events have changed important aspects of their formal arrangements to do with judicial appointments, the functioning of the judiciary, and other constitutional and policy matters, and these changes have attracted criticism both from the domestic opposition groups in each country, and from the EU. The separation of powers has clearly been undermined, and for the time being there cannot be any reliance on goodwill, informal practices or 'suitable personnel' to ensure outcomes better than one might otherwise expect. In both countries, the ruling political party has too much power to allow that, at least for

\footnotetext{
${ }^{10}$ Among democratic countries, we share this distinction only with Israel and New Zealand.

${ }^{11}$ In Northern Ireland, the power-sharing Executive collapsed in January 2017, in the wake of a scandal over a badly managed renewable heating scheme. Since then the leading Northern Ireland political parties have been unable to reach agreement to restore the devolved Executive, with the result that the Province had no functioning government for three years. The Executive was restored in January 2020. Across the UK, devolved government has progressed in different ways in the constituent parts of the country (Wales, Scotland and Northern Ireland). IoG (2019) provides a useful and interesting summary of the past 20 years of political devolution in the UK.
} 
the time being. Moreover, how well a system functions as regards the separation of powers depends not only on the formal arrangements but also on the distribution of political power and the willingness to exercise that power.

What this means is that as far as democracy is concerned, notably those features of democratic polities that form part of the EU's acquis, both Poland and Hungary now fall short of complying fully with the 'EU Model'. As noted, the EU is already taking enforcement action, but the treaty provisions for such action are currently quite weak and may not secure sufficient support from all the other member states. Hence, the EU is facing an interesting test of its determination and capacity to require member states to comply fully with the acquis, including both its political and its economic chapters.

In the economic sphere the EU's ability to insist on full compliance has already been tested, though most significantly in an area not formally covered by the basic treaties. Thus, in the Eurozone it was understood quite early on that some coordination of fiscal policy across the Union might be needed, with limits on deficits, public debt and the like. This wholly reasonable idea gave rise to the Stability and Growth Pact, and since 2012 a European Fiscal Compact embodied these notions in treaty form; 22 member states have signed up for this, namely the Eurozone countries and three others. While very laudable in its intent, several violations of these fiscal principles, including by some of the larger member states, have gone unpunished. In practice, enforcement occurs, if at all, through openness and transparency, in that published fiscal indicators show who is complying with the rules, who is not. What we have, therefore, is a form of what we call in the UK 'naming and shaming', where we like to think that public embarrassment can induce better behaviour by officials and politicians. Sometimes this approach even works, though whether it can do so in an area as politically sensitive as fiscal policy ${ }^{12}$ is uncertain.

On the other hand, this broad approach does seem reasonably efficacious in relation to the EU member states' implementation of the Single Market rules, which are wide ranging and quite complex. The EU publishes each year a Single Market Scoreboard in which it gives detailed data on compliance for each member state. ${ }^{13}$ This tracks new regulations and their transposition into domestic legislation, outstanding cases before the European Court of Justice and compliance with judgements, and shows the progress by each member state over several years, including in comparison to the relevant EU average and targets specified in the Single Market Legislation. All these ensure that enforcement actions are kept fairly low key and routine, while it is clear that the Commission's pressure on any given member state will not cease while there remain issues to be addressed. Perhaps surprisingly, this fairly 'soft' approach to enforcement seems quite effective. Moreover, where these economic rules are concerned, both Hungary and Poland have a good record of formal and officially reported compliance ${ }^{14}$.

\footnotetext{
${ }^{12}$ Moreover, the economic analysis underlying the EU's fiscal rules is itself more than questionable, which gives the member states an opportunity to depart from the rules using sound arguments.

${ }^{13} \mathrm{http}$ ://ec.europa.eu/internal_market/scoreboard/index_en.htm.

${ }^{14}$ However, it did not prevent the Hungarian government from disregarding the formal rules; e.g., by organising a watermelon-cartel which set the price at the level required by the government, and forced retailers to buy only Hungarian watermelons. Subsequently the National Competition Authority declared that it could deal only with companies but not with a ministry-organised cartel. Even worse, the head of the National Tax Authority 'convinced' the MOL company to reduce the gasoline price to an artificially low level just in his municipality. Many similar cases could be quoted, but most such practices are well hidden from the public view.
} 
However, if we only look at the extremely biased public procurement processes in Hungary, notably those linked to EU-support, one may see that such a high level of corruption undermines the free competition and distorts the market seriously. With EU state support for private enterprises at a record level and a super-majority in the legislature, the highly centralized government carries a very powerful stick and carrot policy which convinces the companies to behave subserviently and not to sue the government, even if they are hurt unjustly in some way.

\section{CONCLUSIONS}

Kornai's writings, as I have seen, give us a very good understanding of the failures of central planning in Central and Eastern Europe, and provide a clear picture of the key economic institutions that had to be put in place across the region to enable a successful transition to a well-functioning market-type economy. Most importantly, and quite correctly, Kornai places great emphasis on: private-property rights, market coordination and entrepreneurship. Sections 4 and 5 above sketched out how these basic ideas need to be elaborated to ensure the rule of law and the separation of powers.

In recent years, both Hungary and Poland have departed in various ways from the democratic/political aspects of the 'EU Model' while still largely complying (at least, on the surface) with the EU's economic 'rules of the game'. The EU enforcement of the 'democratic acquis' has so far proved both unwelcome (threatening sovereignty of a member state, undermining local cultural values, etc.) and ineffective (very limited sanctions). There is a significant risk that undermining the 'rule of law' in these countries could inflict damage on the economy, but there is not yet strong evidence for that. In fact, in a period of sustained world economic boom, with zero real interest rates, relatively low world energy prices, and unprecedentedly high EUtransfers and remittances from Hungarians working abroad, strong evidence for such economic harm is difficult to present for those who cannot separate their effects from the direct effect of the government's performance. However, all structural problems, such as insufficient expenditure on research, education, health and social care, emigration of the educated workforce, low fertility, and the reportedly high level of corruption, indicate that the internal sources of economic development are very weak and jeopardize the future welfare of the population seriously. In the meantime, it is important to distinguish between those 'rules of the game' vital for sound economic functioning (thoroughly examined by Kornai in various works), and those that fulfil our preferences for an open and democratic polity. The notion of the 'European values' is an important idea, very much forming part of the EU's acquis communautaire, but perhaps not so critical for the operation of a market-type economy. This difficult and complex interface between the economics and politics of transition, still not well understood, is an area calling for much more research, both conceptual and empirical.

\section{ACKNOWLEDGEMENTS}

This paper was originally written for the special conference held in Budapest in February 2018, to mark the 90th birthday of János Kornai. Since the conference, the paper has been heavily 
revised and updated. I am grateful to Tamás Révész for helpful comments on earlier drafts, together with detailed comments and suggestions from two anonymous referees. Remaining errors are entirely my own.

\section{REFERENCES}

Arak, P. - Bobiński, A. (2017): Poland: Nations in Transit Report. Washington, DC: Freedom House.

Benwell, R. - Gay, O. (2006): The Separation of Powers. Standard Note SN/PC/06053. London: House of Commons Library.

Bingham, T. (2010): The Rule of Law. London: Penguin Books.

BTI (2016a): Hungary Country Report. Bertelsmann Stiftung.

BTI (2016b): Poland Country Report. Bertelsmann Stiftung.

Council (2018): Proposal for a Council Decision.

Dam, K. W. (2006): The Law-Growth Nexus: The Rule of Law and Economic Development. Washington, DC: The Brookings Institution.

De Soto, H. (2000): The Mystery of Capital: Why Capitalism Triumphs in the West and Fails Everywhere Else. London: Black Swan Publishers.

Dewatripont, M. - Roland, G. (1995): The Design of Reform Packages under Uncertainty. American Economic Review, 85(5): 1207-1223.

European Commission (2017): Reasoned Proposal in Accordance with Article 7(1) of the Treaty on European Union Regarding the Rule of Law in Poland: "Proposal for a Council Decision on the Determination of a Clear Risk of a Serious Breach by the Republic of Poland of the Rule of Law". COM(2017) 835 final, Brussels.

European Commission (2018): Communication from the Commission to the European Parliament, the European Council, the Council, the European Economic and Social Committee and the Committee of the Regions: A Modern Budget for a Union that Protects, Empowers and Defends: The Multiannual Financial Framework for 2021-2027. COM(2018) 321 final, Brussels.

European Commission (2019): Communication from the Commission to the European Parliament, the European Council and the Council: Further Strengthening the Rule of Law within the Union: State of Play and Possible Next Steps. COM(2019) 163 final, Brussels.

Freedom House (2018): Freedom in the World 2018. Washington, DC.

Grabbe, H. - Lehne, S. (2018): Could an Illiberal Europe Work? Defending EU Values in Poland and Hungary. Brussels: Carnegie Europe. http://carnegieeurope.eu/2017/09/04/defending-eu-values-inpoland-and-hungary-pub-72988.

Gradzewicz, M. - Growiec, J. - Kolasa, M. - Postek, Ł. - Strzelecki, P. (2014): Poland's Exceptional Performance during the World Economic Crisis: New Growth Accounting Evidence. NBP Working Paper, No. 186, Warsaw: Narodowy Bank Polski.

Gros, D. - Steinherr, A. (2004): Economic Transition in Central and Eastern Europe: Planting the Seeds. Cambridge: CUP.

Halmai, G. - Scheppele, K. L. (ed.) (2012): Opinion on Hungary's New Constitutional Order. Amicus Brief for the Venice Commission on the Transitional Provisions of the Fundamental Law and the Key Cardinal Laws. Council of Europe.

Hare, P. (1991): Central Planning. Chur: Harwood Academic Publishers.

Hare, P. (2015): Comment on "Hungary's U-Turn" by János Kornai. Capitalism and Society, 10(1): 938-963. 
Hare, P. - Révész, T. (1992): Hungary's Transition to the Market: The Case against a "Big-Bang”. Economic Policy, 7(14): 227-264.

Hare, P. - Stoneman, R. (2017): The Evolving Architecture of Europe: Functioning or Dysfunctional for the Twenty-First Century? Comparative Economic Studies, 59(4): 433-471.

Hartwell, Ch. A. (2016a): Two Roads Diverge: The Transition Experience of Poland and Ukraine. Cambridge: CUP.

Hartwell, Ch. A. (2016b): Determinants of Property Rights in Poland and Ukraine: The Polity or Politicians? Journal of Institutional Economics: 1-28, August.

Hayek, F. A. (1944): The Road to Serfdom. London: Routledge.

Hayek, F. A. (1945): The Use of Knowledge in Society. American Economic Review, 34(4): 519-530.

Hegedüs, D. (2017): Hungary: Nations in Transit Report. Washington, DC: Freedom House.

Helsinki (2018): Attacking the Last Line of Defence, Judicial Independence in Hungary in Jeopardy. Hungarian Helsinki Committee. June.

IoG (2019): Devolution at 20. London: Institute for Government.

Jánossy, F. (1966): The End of the Economic Miracle. Appearance and Reality in Economic Development. White Plains, NY: International Arts and Science Press.

Kornai, J. (1959): Overcentralization in Economic Administration. Oxford: OUP.

Kornai, J. (1972): Rush versus Harmonic Growth: Meditation on the Theory and on the Policies of Economic Growth. Amsterdam: North-Holland.

Kornai, J. (1980): The Economics of Shortage. Amsterdam: North Holland.

Kornai, J. (2013): Dynamism, Rivalry and the Surplus Economy: Two Essays on the Nature of Capitalism. Oxford: OUP.

Kornai, J. (2015): Hungary's U-Turn'. Expanded version of paper published in Capitalism and Society, vol. 10: Budapest: Corvinus University of Budapest.

Kornai, J. (2019): Frankenstein’s Moral Responsibility. Acta Oeconomica, 69(4): 485-494.

Lendvai, P. (2017): Orbán: Europe's New Strongman. London: C. Hurst and Co.

Lisbon Treaty (2007): http://www.lisbon-treaty.org.

Maskin, E. (1996): Theories of the Soft Budget-Constraint. Japan and the World Economy, 8: 125-133.

Maskin, E. - Kornai, J. - Roland, G. (2003): Understanding the Soft Budget Constraint. Journal of Economic Literature, 41(4): 1095-1136.

OECD (2018): OECD Economic Surveys, Poland 2018. Paris.

OLAF (2018): Nineteenth Report of the European Anti-Fraud Office. 1 January to 31 December 2018. Brussels: European Commission.

Piroska, D. - Rosta, M. (eds) (2020): The Theories of János Kornai and a Less Known Hungarian Economist, Ferenc Jánossy, on Unbalanced Economic Growth. In: Systems, Institutions and Values in East and West. Engaging with János Kornai's Scholarship. Budapest - New York: Central European University Press, pp. 51-67.

Portes, R. (1991): Introduction. In: The Path of Reform in Central and Eastern Europe. European Economy, Special edition 2. Brussels: Commission of the European Communities, pp. 1-15.

Robinson, J. A. - Torvik, R. (2009): A Political Economy Theory of the Soft Budget Constraint. European Economic Review, 53(7): 786-798.

Rothstein, B. - Varraich, A. (2017): Making Sense of Corruption. Cambridge: CUP.

Sargentini, J. (2018): Draft Report on a proposal calling on the Council to determine, pursuant to Article 7(1) of the Treaty on European Union: "The Existence of a Clear Risk of a Serious Breach by Hungary of 
the Values on which the Union is Founded", 2017/2131(INL). Committee on Civil Liberties, Justice and Home Affairs, European Parliament.

Scheppele, K. L. (2012): The Unconstitutional Constitution. New York Times Opinion Pages, January 2 (linked to Paul Krugman's blog, https://krugman.blogs.nytimes.com/).

Schumpeter, J. (1942): Capitalism, Socialism, and Democracy. New York: Harper \& Bros.

Turley, G. - Luke, P. J. (2011): Transition Economics: Two Decades on. London: Routledge.

World Economic Forum (WEF) (2017): The Global Competitiveness Report 2017-2018. Geneva.

Williamson, C. R. (2010): The Two Sides of de Soto: Property Rights, Land Titling, and Development. In: ChamleeWright, E. (ed.): Annual Proceedings of the Wealth and Well-Being of Nations. Volume 2. Beloit College Press.

Woodruff, Ch. (2001): Review of de Soto's 'The Mystery of Capital'. Journal of Economic Literature, 39(4): $1215-1223$.

World Bank (2008): The Growth Report: Strategies for Sustained Growth and Inclusive Development. Washington, DC.

World Bank (2017): Doing Business 2018: Reforming to Create Jobs. Washington, DC.

$\mathrm{Xu}, \mathrm{Ch}$. (2017): Capitalism and Socialism: A Review of Kornai's 'Dynamism, Rivalry, and the Surplus Economy'. Journal of Economic Literature, 55(1): 191-208. 